\title{
Believing in the Church: Why Ecumenism Needs the Invisibility of the Church
}

\author{
Bradford Littlejohn
}

Political Theory, Patrick Henry College, Purcellville, VA 20132, USA; b.littlejohn@davenantinstitute.org

Received: 30 November 2018; Accepted: 5 February 2019; Published: 12 February 2019

\begin{abstract}
Amidst the plethora of approaches to ecumenical dialogue and church reunion over the last century, a common theme has been the depreciation of the classic Protestant distinction between the "visible" and "invisible" church. Often seen as privileging an abstract predestinarianism over the concrete lives and structures of church communities and underwriting a complacency about division that deprives Christians of any motive to ecumenical endeavor, the concept of the "invisible" church has been widely marginalized in favor of a renewed focus on the "visible" church as the true church. However, I argue that this stress on visible unity creates a pressure toward institutional forms of unity that ultimately privilege Roman Catholic ecclesiologies at the expense of Protestant ones, and thus fails of its ecumenical promise. Renewed attention to Reformational understandings of the relationship between divine grace and human action and the centrality and uniqueness of Christ as the foundation of the church, I argue, dispels some misunderstandings of the church's "invisibility" and demonstrates the indispensability of the concept. I argue that this Reformational framework, which refuses to accept the empirical divisions of the Church as definitive and summons us to an ecumenism that belongs to the church's sanctification, provides the best theological ground for ecumenical endeavor.
\end{abstract}

Keywords: ecclesiology; reformation; invisible church; ecumenism; Richard Hooker; John Webster

\section{Introduction}

Each Sunday, around the world, Christians gather in communities of worship to profess their faith and to witness to the reality of God's action in their midst. Most churches will, at some point during their worship, pause to do something the strangeness of which is too rarely remarked upon: affirm their conviction of their own existence. "We believe in one holy catholic and apostolic Church," they will confess, in the words of the Nicene Creed; or perhaps, in the words of the Apostles' Creed, "I believe in the Holy Spirit, the holy catholic Church, the communion of saints ... ".

The inclusion of the article of the church within the fundamental creed of Christian doctrine has frequently been highlighted as evidence of the importance of ecclesiology, particularly in the face of modern individualism's failure to reckon seriously with the importance of the church in God's purposes for the world. But too rarely do we grapple sufficiently with the significance of the inclusion of this article in our confession of faith: namely, that the existence of the church is discerned only by faith. It is a reality which is invisible to our present gaze. A consideration of the other clauses of the Apostles' Creed highlights this point: each of them confesses our faith in a reality that is either intrinsically invisible to us ("God, the Father almighty"; "the Holy Spirit"), a reality that we trust did happen visibly, but which, being in the past, must now be confessed by faith (most of the clauses regarding Jesus Christ), or a reality which is yet to be revealed to our senses (the final two clauses of the second article; "the forgiveness of sins, the resurrection of the body, and the life everlasting"). In this context, the clauses regarding the holy catholic church and the communion of saints fit plausibly with the last class-realities which are yet to be revealed to our senses. 
Yet a great deal of modern writing on the church and the ecumenical task seems to proceed blithely on the assumption that the church is an empirical reality whose identity, character, and features are indeed readily available to our eyes. We are treated frequently to laments over the disunity of the church, the one thing about the church today that everyone seems able to take for granted as undisputed fact. And yet the Apostle Paul, lamenting the same sorts of divisions that grieve the hearts of modern ecumenists, seems to take for granted that these empirical appearances, the testimony of our eyes and ears about the church, mislead us radically. The church is one, he emphatically insists, although its unity rests in its hidden head, Christ, and the hidden work of His Spirit (1 Cor. 1:10-13; 1 Cor. 12:12-16, 27; Eph. 4:1-6, 16). Modern ecumenism, however, while doing lip-service to this biblical testimony, has frequently proceeded on the assumption that it is our task to make the church one where it is not. ${ }^{1}$

And yet it has seemed that the harder we strive for visible unity, the more this goal has eluded the modern church. Indeed, particularly since the turn of the millennium, many mainline churches have become increasingly pessimistic about the future of the ecumenical project, and in some quarters have shelved these aspirations indefinitely. Evangelical Protestantism, however, which tends to run around three decades behind the mainline in its adoption of theological trends, has in recent years become increasingly agitated about the fact of its own divisions and begun to discuss more seriously the need for forms of visible unity. ${ }^{2}$

In response to mainline ecumenical defeatism and recent evangelical imitations of its misguided assumptions, I propose in this essay to break from recent consensus and argue that it is precisely the church's unity which cannot be visible as such, and that the much-maligned Reformational doctrine of the invisibility of the church offers us the most promising ecumenical ecclesiology. Of course, in so doing, I am well-aware that this ecclesiology will not be ecumenical in its starting point, if by "ecumenical" we mean a theological claim that will be relatively uncontroversial and allow most Christians to sign onto it from the start. Indeed, I would contend that there is no such ecclesiology; part of the tragedy of the ecumenical endeavor has lain in its persistent naïveté about how readily long-standing differences between Roman and Protestant conceptions of the church could be bridged or papered over.

However, my forthrightly Protestant proposal does have the ecumenical advantage of doing justice to the Creed's insistence that our ecclesiology must be one that walks by faith, not by sight.

The remainder of this essay proceeds in three stages. First, I highlight the recent ecumenical consensus for rejecting talk of the church's invisibility and instead pursuing "full visible unity". Second, I argue for a retrieval of the church's invisibility rightly understood, drawing on both Reformation-era resources and the extraordinary recent work of Christoph Schwöbel and the late great John Webster. Third, I draw on analogies with Reformation soteriology and the work of Richard Hooker in particular to provide an account of how we can appropriately seek to make visible the hidden unity that binds the church in one.

\section{The Tragic Quest for Visible Unity}

The first striking feature of much modern ecclesiology and ecumenical endeavor is the widespread consensus that we need to do away with talk of the "invisible church", or any suggestion that an

1 It is important to note up front that most advocates of visible unity seek to guard against this obvious danger. Veli-Matti Kärkkäinen writes, for instance, "it is not the task of the ecumenical movement-or any other human organization for that matter- to create unity between the churches, but rather to give form to the unity already created by God" (Kärkkäinen 2002, p. 85). And Peter Leithart, in the midst of warning against a complacency that accepts the unavoidable reality of difference, still notes that "The church's unity is a fact, rooted in Christ himself" and "We strive for future unity now, prayerfully trusting God to achieve it both now and more perfectly at the end of all things" (Leithart 2016, pp. 18, 19). My contention in this essay, however, is that the urgency of much ecumenical rhetoric and the hastiness of many ecumenical initiatives belies these warnings and creates a kind of Pelagian imperative to create unity where it is not.

2 See, for instance, Leithart (2016); Vanhoozer (2016, chp. 1) surveys various recent critiques and laments of Protestant division. 
"invisible unity" can serve the ecumenical enterprise. Ola Tjørhom, for instance, foregrounds this insistence right in the title of his 2004 Visible Church —Visible Unity, and stresses throughout the need for the church's unity to be visible: "unity belongs inseparably and necessarily to the church's nature" (Tjørhom 2004, p. xvi). Ecumenism has been hampered, in Tjørhom's view, by a kind of Protestantism in "which the church is understood as essentially invisible. As a consequence of this misinterpretation, the church tends to emerge as a kind of societas platonica, or as a mere idea that has no 'body.' ... When the church is described as fundamentally invisible, there will be no room for the concept of visible church unity" (Tjørhom 2004, p. 77). While he does not reject altogether any account of the hiddenness of the church, Tjørhom argues that this Lutheran doctrine has been misunderstood and seeks to re-interpret its confessions to stress the visibility of the church. ${ }^{3}$ Although Tjørhom's passion for visible unity is clear enough, his critique of invisibility is less clear. What does it mean to deny that the church is "essentially invisible" or "fundamentally invisible"? The language of essence and of foundations is in fact critical language in dogmatic ecclesiology, but Tjørhom seems to use these terms loosely as virtual synonyms for "entirely invisible".

More recently, Harold Hegstad begins his The Real Church: An Ecclesiology of the Visible by highlighting, just as I did above, the creedal language "we believe in the Church", and notes that normally we believe in things that we cannot see. But he then goes on, almost immediately, to emphatically reject that this can be the case for the church: "I will argue that the question of what it means to believe in the church cannot be understood by introducing a distinction between the visible and the invisible church. My thesis is that there is only one church, namely the church as visible and one that can be experienced in the world" (Hegstad 2013, p. 2). The doctrine of the invisible church, he insists, is incoherent, lacks biblical support, and makes the church here and now "something unreal in relation to theological ideas about the church" (Hegstad 2013, p. 2). However, betraying more than a little incoherence of his own, he goes on to insist that the church should instead be seen "from an eschatological perspective. From the perspective of faith, the church is understood in light of its future as a sign and anticipation of that fellowship between God and humans which will be brought about by the forthcoming kingdom of God" (Hegstad 2013, p. 2). The reader might well ask whether a future eschatological reality is visible, as such, now-and if not, then does that not mean it is invisible?

In his recent The End of Protestantism: Pursuing Unity in a Fragmented Church, evangelical theologian Peter Leithart poses a similar dichotomy of "invisible" and "eschatological" approaches to unity, insisting that "An invisible unity is not a biblical unity", that "Paul expected-demanded-that the church's unity be visible in table fellowship, in loyalties and allegiances", and that "The unity of the church is not an invisible reality that renders visible things irrelevant. It is a future reality that gives present actions their orientation and meaning" (Leithart 2016, pp. 19, 20). When Michael Allen critiqued Leithart's book from the standpoint of historic Reformed ecclesiological categories, Leithart doubled down on his critique of the invisible/visible distinction as a way to think about the unity of the church. Although "there are invisible dimensions of the church", he argued, they do not pertain to its unity. "The contrast of visible and invisible doesn't correspond to the distinction of unity and disunity; it's not that the church is united invisibly by Christ and the Spirit while it may be disunited in visible respects." In none of the empirical sites of division between Christians, Leithart goes on, "is unity loitering invisibly behind visible disunity." The solution, Leithart again maintains, "lies in the eschatological structure of Paul's understanding of unity" (Leithart 2017).

In his introduction to The Unity of the Church: A Theological State of the Art and Beyond, Eduardus Van der Borght at least seems to recognize that appeals to a hidden invisible unity of the church here and now, or to a future eschatological unity, boil down to much the same thing. Both, he charges, serve as complacent efforts to "take away the sharp edges of [Reformed theology's] unfortunate divisive

3 See particularly Tjørhom (2004, pp. 11-13), where he seeks to downplay the invisibility of the church in the Augsburg Confession, and p. 7, where he goes so far as to say, "the Reformers ... were firmly committed to keep the episcopal order or polity of the Church." 
tendency" (Van der Borght 2010, p. 1). Later in the volume, Amie van Wyk elaborates on this critique, seeing these doctrines as "justifications of division" and as "eschatological escapism" (Van Wyk 2010, pp. 62, 65). Ironically, however, just two pages later, van Wyk seems to resort to just this "escapism": "The realization of the unity of the church of Christ is in the last instance a question about our trust in God. Do we really trust God that one day He will bring to completion what He has promised?" (Van Wyk 2010, p. 67).

Although recent critics of the invisibility of the church seem to have been more passionate than precise, they speak for a decades-long consensus in favor of the church's visibility. John Webster remarks, "The consensus of much recent ecclesiology has been ... [that] no ecclesiology can be adequate which does not give primacy to the church's visibility" (Webster 2004a, p. 24). In keeping with this theological consensus, the establishment of increasingly visible forms of unity has served as the basic objective of the ecumenical project, culminating, for many ecumenists, in "full visible unity". This language has played a particularly prominent role in Anglican-Roman Catholic dialogue and in John Paul II's crucial encyclical, Ut Unum Sint: "The ultimate goal of the ecumenical movement is to re-establish full visible unity among all the baptized" (Paul 1995, §77). ${ }^{4}$ More generally, Veli-Matti Kärkkäinen writes, "With the exception of most Free churches, almost all other Christian churches currently regard visible unity as the desired goal of ecumenism" (Kärkkäinen 2002, p. 84).

But what do we mean when we call for visible unity in the church? Many different answers might be proposed and have been proposed over the course of the ecumenical movement. Certainly, we might mean a unity of confession - a situation in which all Christians around the world profess the same body of truths, or at least the same body of fundamental doctrines, jointly acknowledging that the remaining points of difference are secondary or tertiary. We might also have in mind a unity of worship - a situation in which churches, while not liturgically identical, at least exhibit a common practice of the core rites of Christian worship and, just as importantly, recognize one another's rites as valid. Additionally, if the church is in some sense an institution and is meant to exhibit visible unity, then it seems as if institutional unity must be a goal-some kind of shared structure of oversight and authority which binds all churches together into a self-regulating or at least mutually-regulating whole. Finally, we might speak of a missional unity, in which the various churches commit to working together for the proclamation of the gospel and the healing of a broken world.

All four of these have been highlighted in various ways by the modern ecumenical movement. The last, however, missional unity, although generally granted to be essential to the broader ecumenical enterprise and indeed perhaps most critical of all at the grassroots level, does not play as key a role in formal ecumenical discussions and documents. This is natural enough, given that the work of mission will always be particular, local, and contextual, and thus, there is little point in trying to flesh out in advance the shape of a shared commitment to mission. The Meissen Agreement thus stands as a good representative of many ecumenical documents in its commitment to the first three forms of "full, visible unity":

-a common confession of the apostolic faith in word and life ...

-the sharing of one baptism, the celebrating of one eucharist and the service of reconciled, common ministry. This common participation in one baptism, one eucharist and one ministry unites 'all in each place' with 'all in every place' within the whole communion of saints ...

-bonds of communion which enable the Church at every level to guard and interpret the apostolic faith, to take decisions, to teach authoritatively, to share goods and to bear effective witness in the world. The bonds of communion will possess personal, collegial and communal aspects (Church of England 1991, §8).

4 Webster $(2004 \mathrm{~b}, 2008)$ critically surveys the prominence of the language of "full visible unity" in modern Anglican-Roman Catholic dialogue; for a broader survey of recent models of ecumenism, see Vischer et al. (2008, pp. 19-27). 
The wording here, as in most such documents, carefully avoids the language of "institution", which is something of a dirty word in the modern world, and takes refuge in the more comfortable language of "communion" ${ }^{5}$ or of sacramental unity. ${ }^{6}$ Indeed, one of the great achievements of so-called "communion ecclesiology", particularly in the Roman Catholic Church, was to move discussions of the church from an unhealthy focus on hierarchy, authority, and formal structures to the way that the life of the church is constituted by bonds of common life sustained by laity as much as clergy. ${ }^{7}$ Still, there is no avoiding the fact that "guarding", "interpreting", "taking decisions", and certainly "teaching authoritatively" involve authorities, and ultimately authority structures-which is to say institutions by which those authorities are authorized, within which they function, and whose boundaries they guard. Indeed, in their work Unity of the Church in the New Testament and Today, Lukas Vischer and his co-authors acknowledge this fact: "The unity we are seeking exists only as a unity that can be seen and demonstrated, or it does not exist at all. It is institutional unity, or else it remains a phantom" (Vischer et al. 2008, p. 231).

Within Anglican and Roman Catholic ecumenical endeavors at least, it has generally been assumed that these authority structures must lie in the historic episcopate, and even that some form of papal primacy might need to be conceded as its point of integration. ${ }^{8}$ Naturally, such an account would require the exclusion of all those who do not accept these authority structures from the reunited church. The result, as Donald MacLeod shrewdly observes, is that while documents like Ut Unum Sint are framed in terms of a dialogue of mutual reconciliation, "It looks, however, as if the full price of any reconciliation must be paid by Protestants" (MacLeod 2008, p. 77).

Indeed, what is too often left unvoiced in these discussions is that, however much we might like to stress the life-giving core of the church's unity, any account of visible unity must ultimately give an account of the outer boundaries of the church's unity. After all, if we can see what it is that holds together any given thing, then we can also at the same time see what it is that holds it apart from everything else. When I glance at the books on my shelves, I can instantly recognize one book as one book by its spine, the bond of unity that holds the various pages together. If were to flip all my books around so that the pages faced me in one undifferentiated mass, I would still be able to rely on the distinct binding of each book to separate it from the others. The very thing that keeps many pages together as one thing is the same thing that excludes other pages as not that thing. It is the same in the church. We often recognize this clearly enough at the front end of the ecumenical task, observing that the very things that bind us together into distinct denominations or traditions are the things that clearly mark us off from other groups of Christians. But too often, as we gaze into the mists of the future with rose-tinted spectacles, we forget that the same must be true of the church of the future. To whatever extent our churches are visibly united, they will have the means to exclude all those outside their union, and once the church attains "full visible unity", this will entail an institutional church with the capacity to authoritatively define who is in the church and who is not.

This is true, mind you, even if we lay the stress on a unity of confession, for there will always be many religious groups claiming to be Christian and clamoring to be recognized as such whose doctrine will be suspect; and "full visible unity" will require a mechanism for adjudicating their claims and thus either including or excluding them. Peter Leithart is one recent ecumenical theologian who is to be credited with at least being explicit about the need for such boundary-marking:

Guided by Scripture above all and by the Christian tradition, the [reunited future] church will issue binding judgments about which deviations are tolerable and which are intolerable. Some opinions and teachers will be judged a threat to the gospel itself, and impenitent

\footnotetext{
See, for instance, Kärkkäinen (2002, pp. 85-87, 95-102) and Jenson (1997).

See, for instance, Tjørhom (2004, pp. 70-71).

For a helpful survey, see Murphy (2008). For a critique, see Webster (2004a, pp. 14-21).

See Morerod (2008); Webster (2008); Davie (2004).
} 
teachers will be expelled from the church.... [T]he reunited church will have one advantage over the churches of today: expulsion from the reunited church will be plausibly seen as expulsion from the church. It will not be expulsion from one denomination that leaves the expelled with the option of going down the road to start his or her own denomination (Leithart 2016, pp. 29-30).

The problem with this, of course, is that it suggests that the terminus of ecumenism might be some kind of sectarianism-however large the sect may be. The quest to make the church one requires, on this account, adopting criteria whereby one can say, "this group of churches belongs to the one, holy, catholic, and apostolic church, and the rest of you do not." Those making such claims are usually careful to draw the criteria of ecclesial identity around their own traditions, or else, worrying that their traditions are deficient when it comes to the visible boundary-markers, jump ship to other traditions, effectively unchurching those from which they began. Many find themselves beginning the ecumenical enterprise with a more capacious account of the being and form of the church, which paradoxically shrinks under the pressure of the ecumenical project; and often, I would argue, in precise proportion to their fear of sectarianism. Indeed, Ola Tjørhom is but one particularly striking example of the frequent pattern of the modern-day ecumenist who began by looking for a visible unity of all Christian denominations and ended by despairing of this quest and joining the Roman Catholic Church. ${ }^{9}$

To point this out is, of course, not to dismiss the possibility of Roman Catholic ecclesiology; it is simply to acknowledge that it is, in fact, a particular ecclesiology, one that does foreground visible unity, and that naturally therefore excludes genuine union with churches that do not accept the terms of that visible unity. To begin the ecumenical quest with a demand for visibility and seek to create such visibility by human action is to begin on un-Protestant premises, and thus naturally terminates in an un-Protestant and ultimately exclusive (rather than genuinely ecumenical) church. It is the burden of the latter half of this essay to argue that it might be worth giving the long-neglected Protestant premises another try and see whether they might not hold the seeds of a more genuinely ecumenical ecclesiology.

\section{Restating the Invisibility of the Church}

\subsection{Invisible Foundations}

At the outset of my effort at a constructive retrieval of the church's invisibility, it would be foolish to deny that its critics have a point. Talk of an "invisible church" can serve, and frequently has served, as a complacent salve to persistent divisions that demand healing and reconciliation if we are to be faithful to Christ. And quite clearly, the church cannot be merely invisible-it is made up of people, after all, who are thoroughly visible-nor can its unity be merely invisible, since these people do things together. Of course, it is doubtful whether any mainstream Christian tradition has ever denied these points, but it is true that the language of an "invisible church" tends to have a static rather than dynamic sound to it, as if the church simply always were, and always would be invisible, and that is all there was to it.

No doubt it is for this reason that many contemporary critics of the church's invisibility have preferred to speak of the "hiddenness" of the church or of an eschatological, rather than invisible unity. This language suggests that although many aspects of the church's unity may remain presently invisible, we expect and await their unveiling. However, this language also blurs important distinctions. For while everyone might admit that we, in some sense, await a future visible unveiling of the church's true glory and unity, it matters a great deal which aspects, we think, may happen within history, and which aspects await the return of Christ. I argue here that clear dogmatic reflection on the invisibility of the church will chasten our expectations of what kind of visible unity to expect within this mortal age.

$9 \quad$ See Tjørhom (2004, preface). 
Given many ecumenists' preference for an idea of a movement from invisibility toward visibility, it is perhaps ironic that Ola Tjørhom directs his criticism against the idea that the church is "fundamentally invisible". In fact, I would suggest that if there is any sense in which the church is invisible, it is precisely in this sense-fundamentally - that is, in terms of its foundations. The church is a visible structure built upon a foundation that is presently invisible to human eyes: The absent Jesus Christ. Or, to opt for a more organic metaphor, the church is a plant that has its being, its common life, in a root that lies hidden underground-Christ, from whom it first grew and by whom it is still nourished. This, then, is the first thing that we must say about the invisibility of the church: That the source of the church's life is invisible. The church is the visible body of Christ, but the soul that animates that body, so to speak, is the body of our ascended Lord-visible in itself, to be sure, as a true body, but not visible to our eyes this side of the eschaton.

Of course, this is another way of saying that the church lives not of herself, or by the actions of her human members, but by the power of the Word of God and the action of the Spirit. Otherwise, the church would not be the church, but merely another religious association or social club. As Christoph Schwöbel puts it, "The Church is creatura verbi divini: the creature of the divine Word. The church is constituted by God's action and not by any human action. It is not an association of people who have a shared taste for religion or the creation of some kind of human community spirit" (Schwöbel 1989, p. 122). Of course, we might ask why such a sharp distinction between divine action and human action is necessary. Why can we not say that God acts through human agents and therefore, divine action is, to this extent, visible? This was, to be sure, the Roman Catholic position that the Reformers opposed, and versions of it have become increasingly fashionable in modern theology, which is particularly impatient of distinctions-as evidenced by the studied vagueness of the pervasive koinonia concept within ecclesiology. However, the distinctions that the Reformers drew remain important, as both Schwöbel and John Webster have lucidly argued.

"According to the Reformers," notes Schwöbel, "God's action and human action have to be strictly distinguished in order to perceive their proper relationship ... God's work is always the condition of the possibility of all human action" (Schwöbel 1989, p. 119). Webster elaborates,

God may choose to act through creatures; in doing so, he elevates the creature but does not bestow an enduring capacity on the creature so much as consecrate it for a specific appointment. And in its acts, the creature remains wholly subservient, ministerial, and ostensive. The ontological rule in ecclesiology is therefore that whatever conjunction there may be between God and his saints, it is comprehended within an ever greater dissimilarity (Webster 2004a, p. 21).

What this means is that human action can never claim to be self-attesting in the way that divine action is, cannot in itself demand recognition as divine action. The church carries out what, to merely temporal eyes, appear to be mundane human actions; it is a visible as "a human gathering; it engages in human activities; it has customs, texts, orders, procedures, possessions, like any other visible social entity. But how does it do and have these things? It does and has these things by virtue of the work of the Holy Spirit" (Webster 2004a, p. 25)

But how do we know that the when this group of people reads texts and performs symbolic actions, it does so as the church, as the body of Christ and the community of the Spirit? Well, by the eyes of faith; we believe in the church, but do not see it qua church. Webster, again, puts it brilliantly:

Accordingly, knowledge of the church cannot be derived in a straightforward way by deduction from its visible phenomena and practices. Only through the Spirit's agency are the phenomena to be grasped as phenomena of the church. The church is known as God is known, in the knowledge which comes from God's self-communicative presence, of which the human coordinate is faith. Only in this spiritual knowledge is the church known and its phenomena seen as what they are. Faith does not, of course, perceive a different, 'hidden' set 
of phenomena, behind the natural-historical realities of the church's visible acts. It sees those acts as what they are: attestations of God (Webster 2004a, p. 27).

This, then, is one key function of the doctrine of the invisibility of the church: "Properly defined, the concept of the invisibility of the church is a standing denial of any easy identification of divine and human work" (Webster 2001, p. 73). The church is invisible inasmuch as it remains the work of God, irreducible to human action, and God remains invisible. Schwöbel summarizes elegantly:

The 'invisibility' of the Church refers to God's act in constituting the Church which, as the power to create a visible community of witness, is itself invisible. The distinction between the 'invisible' and 'visible' Church can be more adequately interpreted if we relate it to the question how the Church can be an object of faith which is confessed in the Creed and how it can be field of human action. Only as creatura verbi divini is the Church an object of faith, because only God's action in establishing and disclosing the true relationship between the creator and his creation that makes faith possible can be confessed as the content of faith. As the community of witness which proclaims the truth of God's revelation it is a human field of action (Schwöbel 1989, pp. 130-31).

The visibility of the church is thus every bit as essential to the full definition of the church as the coordinate without which the invisibility would be meaningless: the invisibility is in God's power to create and sustain a community of witness; the visibility is in the community thereby created, and in the witness it offers through its human actions.

\subsection{Invisible Unity}

Still, this is not all that needs to be said about the invisibility of the church; indeed, if it were, I would have little to add to Schwöbel and Webster's illuminating treatments. We must also deploy the concept of the invisibility of the church specifically with reference to its unity and its boundaries, the essential issues at stake in ecumenical theology.

Critics of the doctrine of the invisibility of the church, from counter-Reformation Catholic polemicists right down to the present, have frequently characterized it as creating two different entities, "the visible and invisible churches", as if we were referring to two different entities. Defenders of the concept will frequently push back by insisting that this is all wrong, and what we have are simply visible and invisible aspects of the same entity; indeed, Schwöbel and Webster are both consistent in using this language. This is true, but I do not think it is the whole story. We can get a sense of why by considering Richard Field's uncommonly lucid but sadly neglected 1606 treatment:

we say that there is a visible and invisible church, not meaning to make two distinct Churches, as our adversaries falsely and maliciously charge us . . . but to distinguish the divers [sic] considerations of the same Church; which though it be visible in respect of the profession of supernatural verities revealed in Christ, use of the holy sacraments, order of ministry, and due obedience yielded thereunto, and they discernible that do communicate therein; yet in respect of those most precious effects, and happy benefits of saving grace, wherein only the elect do communicate, it is invisible; and they that in so happy, gracious and desirable things have communion among themselves, are not discernible from others to whom this fellowship is denied, but are known only unto God. That Nathaniel was an Israelite all men knew; that he was 'a true Israelite, in whom was no guile,' Christ only knew.

The persons, then, of them whom the Church consisteth are visible; their profession known even to the profane and wicked of the world, and in this sort the Church cannot be invisible $\ldots$

Notwithstanding, because the truth and excellence of the faith and profession of Christians, is not discerned by the light of nature, but by faith alone; the excellency of this society of 
Christians above other profane companies in the world, and their happiness that are of it, is invisible, hidden and unknown to natural men, and is known only to them that are spiritual. And who they are that have fellowship among themselves, not only in the profession of heavenly verities and outward means of salvation, but also in the benefits of effectual and saving grace, is known neither to the natural nor spiritual man, but to God alone (Field 1847, vol. 1, p. 32).

Field here begins with the language of "divers [sic] considerations of the same Church" but spells it out in such a way that we are necessarily referring to distinct groups of people. The people who are in the church are visible to human eyes, but which people are in the church is not visible to human eyes. Although the language of election may be unfashionable, and one of the most common criticisms of the invisible church may be its association with Calvinistic predestinarianism, Field's argument is a necessary consequence of what we have said thus far. The church cannot merely be another something that humans do. It must be something that humans united to Christ and empowered by the Spirit do. The church is constituted by divine action. And although humans united to Christ and empowered by the Spirit may tend to exhibit distinctive marks, these marks are not self-authenticating; the spiritual man can discern by faith the reality which they signify, but even the eyes of faith cannot infallibly discern where the reality is and is not present. It is clear that there are many who profess to belong to Christ and do not. "Not everyone who says to me, 'Lord, Lord,' will enter the kingdom of heaven, but the one who does the will of my Father in heaven" (Mt. 7:21). It is equally clear that the difference is not reliably observable by empirical criteria: "On that day many will say to me, 'Lord, Lord, did we not prophesy in your name, and cast out demons in your name, and do many mighty works in your name?' And then I will declare to them, 'I never knew you; depart from me, you workers of lawlessness" (Mt. 7:22-23).

The church is thus a body of visible people, and yet, as a body, is invisible. As Richard Hooker writes,

Nor can that body be perceived by any one's senses, since some of its members are already with Christ in heaven, and as for the rest, although we can see their bodies on earth, we cannot peer into their souls, and so do not know with certainty whether they belong to Christ's body. Only with our minds can we conceive of this body, containing a huge multitude, a real body and yet invisible, because the nature of its union is utterly beyond our sense experience (Hooker 2018, p. 47).

This is the point I am keen to stress here: As the source of the church's life is invisible, so is the bond of its union; and if the bond of its union is invisible, so are its boundaries of separation. We cannot say that the church has visible and invisible aspects in simply the same way as an iceberg does-the human beings who make it up are visible above the surface, and Christ who gives it life is hidden-or even in the way that we might speak of a human body as visible and the animating force that gives it life as invisible. The church is a unity, but a composite unity, made up of many individuals, and which individuals remains unknown to us. If we may go back to the analogy of plant and root and extend it in perhaps a disconcerting — but hopefully illuminating — direction, we may consider a cluster of dandelions. Dozens of dandelions might appear above ground which turn out to be a single organism, sharing a common root structure. But the fact that their bond of unity remains hidden means that at the same time so does their boundary of separation — there may be other dandelions in close proximity which are not, in fact, part of the same organism, but there is no way we can discern this from above. The analogy fails, of course, at the point when we note that those who are not truly of Christ's church are not members of another church, but members of no church at all. But the point remains that when we look out upon the multitude of professing Christians, we know that some are united to Christ, and thus are the church, and some are not.

Not knowing which are which, we are admonished by Hooker and other Protestant theologians not to try too hard to guess, but to extend a judgment of charity, treating all those who profess Christ 
as members of His visible church. ${ }^{10}$ However, we should not shy away from the fact that this does give us in some sense two churches: one body of individuals who are indeed the church, and another larger body, including all these but also many more, that is a corpus permixtum of believers and unbelievers. This confession of the church's invisibility is, thus, a standing rebuke to the misguided projects surveyed in the case studies above, in which the attempt to identify visible historical guarantees of where the church was ended in a sectarian conclusion about where the church was not.

\section{The Task of Witness: Making Unity Visible}

If this were all we had to say, the critics of the invisibility of the church would have a fair point. Must we rest content with a negative ecclesiology and simply dismiss all efforts at visible unity or meaningful boundary-drawing as futile and perhaps Pelagian? After all, the same Christ who admonished us that "Not everyone who says to me, 'Lord, Lord,' will enter the kingdom of heaven," also said—in the immediately preceding verse-“"By their fruits you will know them" (Mt. 7:20). Thus, nearly all Christian traditions have practiced various forms of church discipline, seeking to cut dead branches-those who have thoroughly repudiated the teaching of Christ or the obedience He demands - off the vine of the church to maintain its purity.

If we are still called to protect the purity of the church despite the limits of our vision, are we not also called to pursue the visible unity of the church even while recognizing its invisible root? Ecumenists may breathe a sigh of relief to hear me say "Yes!" But again, I will argue that it is Reformational doctrine that provides us the best compass for this pursuit.

We have noted already the continuity between Reformation ecclesiology and soteriology-our confession of the church's dependence on God's gracious action is an extension of a broader confession of that God's prevenient grace precedes, makes possible, and is never absorbed into human action. Thus, I would suggest that our ecclesiology can also learn from Reformation soteriology's distinction of justification and sanctification. Richard Hooker summarizes the distinction crisply:

There is a glorifying righteousness of men in the world to come: and there is a justifying and a sanctifying righteousness here. The righteousness, wherewith we shall be clothed in the world to come, is both perfect and inherent. That whereby here we are justified is perfect, but not inherent. That whereby we are sanctified, inherent, but not perfect ${ }^{11}$ (Hooker 1990, p. 109).

In the grace of justification, the believer lives eccentrically, her life hidden in Christ, resting upon the perfect and complete righteousness that is found only in Christ. Just so, the church lives not of herself, but in her Head, Christ, her perfect life contained invisibly in Him. In the grace of sanctification, Christ by His Spirit empowers those who live in Him to live like Him, or to at least make some small beginning in that direction; righteousness thus becomes inherent in them, but always imperfect. Just so, the church, through the power of the Spirit, is enabled bit by bit, haltingly and inconsistently, to visibly manifest her hidden identity, so that the unity and holiness which she has perfectly in Christ come to exist imperfectly but really in her external structures and common life. Finally, at the consummation, the believer looks forward to glorification, in which the perfect but extrinsic righteousness of justification and the imperfect but inherent righteousness of sanctification come together, and the life of Christ is fully manifest in the perfected believer. Similarly, the church looks forward to the eschaton when, purged of her corruptions and false professors, and fully united in faith and love, she becomes fully and truly one holy bride of Christ for all eyes to see.

This framework gives us a basis for genuinely seeking to make the invisible reality visible-thus the legitimacy of a quest for visible unity - while also warning us against a confusion of our present

10 For a fuller discussion, see Littlejohn (2015, chp. 10).

11 I have modernized spelling and punctuation in this quotation from Hooker and the one which follows. 
work with Christ's final glorifying work, and against unrealistic expectations for what we can make visible here and now. This idea of making the invisible visible is captured well in Schwöbel and Webster's concept of "witness", as well as Hooker's concept of "correspondences", both of which we briefly explore before drawing some concluding applications.

We have already seen Schwöbel's language of the church as a "community of witness". What does it mean to witness? The task of a witness is ostensive, to point to the activity of another, and to attest it, to corroborate for those seeing or hearing that someone else really has done, or is doing, something. "Testimony," says Webster, "is astonished indication. Arrested by the wholly disorienting grace of God in Christ and the Spirit, the church simply points" (Webster 2004a, p. 29). This is the task of the visible body of believers - to point to the activity of Christ in their midst and attest its reality. "The active visibility of the church consists in attestations of the word and work of the God who is its creator, reconciler, and consummator," says Webster (Webster 2004a, p. 28). Of course, the way in which we do this is a distinctive form of witness: We do not merely speak about the activity of Christ, or rest passively in it, but we actively manifest it in our lives and relationships, by seeking to conform our common life to the standards laid down for the church. Attestation, says Webster, "is a summons to act in particular ways which are shaped by the truth of the gospel. That means that the church is appointed to visible activity which is in accordance with the given fact that the world is the sphere in which the triune God's antecedent grace is wholly victorious and resplendent" (Webster 2004a, p. 29)

In short, we structure our common life in ways that help to make apparent to a watching world that we really are what we claim to be and, thus, that God really is who He claims to be. This concept of witness or attestation can thus be further fleshed out by reference to Richard Hooker's concept of "correspondences". Hooker in some ways offers one of the most minimalist ecclesiologies to be found in the Reformation period, arguing that in some sense even "impious idolaters, wicked heretics, men worthy of excommunication, or indeed already cast out for great wickedness" are still members of the visible church as long as they profess Christianity. ${ }^{12}$ However, he balances this minimalism with his doctrine of correspondences, his insistence that the church outwardly ought to seek to correspond to its inward reality. "Signs must resemble the things they signify," he declares, and we might legitimately speak of the visible church, in his theology, as a sign which signifies the presence of the invisible. Accordingly, it must strive to manifest outwardly the qualities which it has antecedently in Christ:

That which inwardly each man should be, the Church outwardly ought to testify. And therefore the duties of our religion which are seen must be such as that affection which is unseen ought to be. Signs must resemble the things they signify. If religion bear the greatest sway in our hearts, our outward religious duties must show it, as far as the Church hath outward ability ... Yea then are the public duties of religion best ordered, when the militant Church doth resemble by sensible means, as it may in such cases, the hidden dignity and glory wherewith the Church triumphant in heaven is beautified (Hooker 1977, pp. 33-34).

By this means, Hooker brings together the "hidden dignity and glory" of the church hidden in Christ with the imperfect worship and life of the church as it appears on earth. In the act of public worship, the visible church symbolically enacts the believer's inward worship of God, and indeed aids it, serving "as a hand to lead and a guide to direct", but the two planes are not confused. Similarly, the structures that maintain the visible church's unity and enact its discipline should seek to manifest the unity and purity antecedently given in Christ, so that the outward corresponds to the inward. Hooker, accordingly, is well-prepared to argue at length for the importance of historical structures of authority, visible forms of unity, diligent observance of the sacraments, and submission to creedal and confessional norms as the signs and seals of the church's catholicity, crucial to its sanctification and

12 See Hooker (2018, pp. 47-62). 
well-being. ${ }^{13}$ And we must work to restore them to our churches. But these things do not constitute the church's being, the basis of its recognition before God. That is hidden with Christ in God, and our first task is ensure that we, and those in our own churches, are sharing in this life, not to obsess over the criteria for other churches to share in it.

\section{Conclusions}

This thus leads us back to some closing observations on ecumenism, ecclesiology, and the search for visible unity. Much of what I have said here about "attestation" and "correspondence" suggests that there is an imperative for churches to seek visible unity, in all its forms: unity of confession, unity of worship, and missional unity at the very least, and at least a level of institutional unity that helps to serve these functions (although most Protestants would argue that this would be better accomplished by conciliar or federal instruments of unity than consolidation under a primate). Despite my critique of much recent ecumenism early in the essay, it should be clear by now that my purpose is not to dismiss or minimize the pursuit of unity, but rather to resituate it on firmer theological grounds. By dismissing the invisibility of the Church, much modern ecumenical theology has committed itself to a self-destructive form of the search for visible unity, one which cannot help ultimately identifying the being of the Church with empirical institutional forms and at least implicitly unchurching those Christians who do not share them. It has also placed an intolerable burden on the ecumenical task, sometimes implying that our efforts toward unity are necessary to put the broken pieces of the body of Christ back together. ${ }^{14}$

By contrast, if we start from the doctrine of the church's invisibility, this can have, as Schwöbel says, "a radically liberating effect for the church". Rather than feeling the burden of doing God's work for him, "We can only witness to God's faithfulness who will complete the work he has begun by creating the Church as the creature of the divine Word." (Schwöbel 1989, p. 150). Indeed, says Schwöbel, quoting from Calvin, "If we interpret God's action as the foundation for the unity of the Church we do not need the visible evidence of a united empirical church: ' $\ldots$ in order to embrace the unity of the church in this manner, it is not necessary, as I have observed, to see it with our eyes or feel it with our hands.'” (Schwöbel 1989, p. 141, quoting Calvin 1846, vol. III, p. 13). This approach calls us to accept a certain flexibility and provisionality toward the structural forms which different expressions of the Church take across history and at any given time and beware of making any given form a sine qua non of ecclesial identity or Christian communion. "No human institution or church office or set of rules for the practice of the ministry of the word can as such be a theologically necessary condition for community with other churches ...." (Schwöbel 1989, p. 153). Though we may have good grounds for favoring episcopal ministry as the most well-suited to the service of the church, and good grounds for seeking a shared recognition of episcopal ministry among all churches, we will need to accept the fact that this shared ministry will lie at the end, rather than beginning, of the church's long hard endeavor to attest the unity she has in Christ.

To say anything else, in over-hasty pursuit of visible unity, is actually to take the sectarian path rather than the ecumenical one, marginalizing all branches of the church which lack "valid ministerial orders" (or whatever the criterion might be). As Webster notes,

the unity of the church is not generated or kept by the episcopate. Unity is pure gift; it is brought about by Christ himself .... And so we must say that 'The ministry of the church can neither create nor represent this unity, but only make it visible through the fact that it points unmistakeably away from itself and toward that which it serves-the present action

13 For more on these elements in Hooker's ecclesiology, and their relationship to his key distinctions of the visible and invisible church, see Littlejohn (2015, chps. 10-11).

14 See for instance (Leithart 2016, pp. 1-6). 
of Christ in the proclamation of the Gospel through word and sacrament' (Webster 2001, p. 79, quoting Dalferth 1997, p. 42).

In short, an ecumenical ecclesiology that begins in worried introspection must end in either a despairing or triumphalist gaze into the mirror, examining the visible structures of the church to determine whether the body of Christ is sufficiently united yet. A truly ecumenical ecclesiology must instead both begin and end in the confident extrospection of faith, trusting in the Lord of the church to complete His sanctifying and glorifying work in her.

Funding: This research received no external funding.

Conflicts of Interest: The author declares no conflict of interest.

\section{References}

Calvin, John. 1846. Institutes of the Christian Religion. Translated by Henry Beveridge. 3 vols, Edinburgh: Calvin Translation Society.

Church of England. 1991. The Meissen Agreement. Available online: https:/ /www.churchofengland.org/sites/ default/files/2017-11/meissen_english.pdf (accessed on 30 November 2018).

Dalferth, Ingolf. 1997. Ministry and the Office of the Bishop according to Meissen and Porvoo. In Visible Unity and the Ministry of Oversight: The Second Theological Conference Held under the Messien Agreement between the Church of England and the Evangelical Church in Germany. London: Church House Publishing, pp. 9-48.

Davie, Martin. 2004. Anglican Ecumenism: The Liberal Catholic Consensus and the Conservative Evangelical Challenge. In Paths to Unity: Explorations in Ecumenical Method. Edited by John Cicester. London: Church House Publishing, pp. 29-51.

Field, Richard. 1847. Of the Church: Five Books, Reprint, ed. 4 vols, Cambridge: Cambridge University Press.

Hegstad, Harald. 2013. The Real Church: An Ecclesiology of the Visible. Eugene: Pickwick.

Hooker, Richard. 1977. Of the Laws of Ecclesiastical Polity, Book V. In The Folger Library Edition of Richard Hooker: $V$. Tractates and Sermons. Edited by W. Speed Hill. Cambridge: Belknap Press.

Hooker, Richard. 1990. A Learned Discourse of Justification, Workes, and How the Foundation of Faith is Overthrowne. In The Folger Library Edition of Richard Hooker: V. Tractates and Sermons. Edited by Laetitia Yeandle and Egil Grislis. Cambridge: Belknap Press, pp. 83-169.

Hooker, Richard. 2018. The Word of God and the Words of Man: Books II-III of Hooker's Laws: A Modernization. Edited by Bradford Littlejohn, Bradley Belschner and Brian Marr. Moscow: Davenant.

Jenson, Robert. 1997. The Church and the Sacraments. In The Cambridge Companion to Christian Doctrine. Edited by Colin Gunton. Cambridge: CUP, pp. 207-25.

Kärkkäinen, Veli-Matti. 2002. An Introduction to Ecclesiology: Ecumenical, Historical, and Global Perspectives. Downer's Grove: IVP Academic.

Leithart, Peter. 2016. The End of Protestantism: Pursuing Unity in a Fragmented Church. Grand Rapids: Brazos.

Leithart, Peter. 2017. Attaining Unity: A Reply to Mike Allen. Theopolis Institute. Available online: https: / / theopolisinstitute.com/article/attaining-unity-a-reply-to-mike-allen (accessed on 30 November 2018).

Littlejohn, W. Bradford. 2015. Richard Hooker: A Companion to His Life and Work. Eugene: Cascade.

MacLeod, Donald. 2008. The Basis of Christian Unity. In Ecumenism Today: The Universal Church in the 21st Century. Edited by Francesca Aran Murphy and Christopher Asprey. Aldershot: Ashgate, pp. 107-20.

Morerod, Charles. 2008. The Ecumenical Meaning of the Petrine Ministry. In Ecumenism Today: The Universal Church in the 21st Century. Edited by Francesca Aran Murphy and Christopher Asprey. Aldershot: Ashgate, pp. 121-38.

Murphy, Francesca Aran. 2008. De Lubac, Ratzinger and von Balthasar: A Communal Adventure in Ecclesiology. In Ecumenism Today: The Universal Church in the 21st Century. Edited by Francesca Aran Murphy and Christopher Asprey. Aldershot: Ashgate, pp. 45-80.

Paul, John, II. 1995. Ut Unum Sint: On Commitment to Ecumenism. The Vatican: St. Paul Books \& Media.

Schwöbel, Christoph. 1989. The Creature of the Word: Recovering the Ecclesiology of the Reformers. In On Being the Church: Essays on the Christian Community. Edited by Colin E. Gunton and Daniel W. Hardy. Edinburgh: T\&T Clark, pp. 110-55. 
Tjørhom, Ola. 2004. Visible Church—Visible Unity: Ecumenical Ecclesiology and the "The Great Tradition of the Church". Collegeville: Liturgical Press.

Van der Borght, Eduardus. 2010. The Unity of the Church in the Reformed Tradition: An Introduction. In The Unity of the Church: A Theological State of the Art and Beyond. Edited by Eduardus van der Borght. Leiden: Brill, pp. 1-15.

Van Wyk, J.H. (Amie). 2010. "Is Christ Divided?"-An Analysis of the Theological Justification of a Church Schism. In The Unity of the Church: A Theological State of the Art and Beyond. Edited by Eduardus van der Borght. Leiden: Brill, pp. 51-68.

Vanhoozer, Kevin. 2016. Biblical Authority After Babel: Retrieving the Solas in the Spirit of Mere Protestant Christianity. Brazos: Grand Rapids.

Vischer, Lukas, Ulrich Luz, and Christian Link. 2008. Unity of the Church in the New Testament and Today. Grand Rapids: Eerdmans.

Webster, John. 2001. The Self-Organizing Power of the Gospel of Christ: Episcopacy and Community Formation. International Journal of Systematic Theology 3: 69-82. [CrossRef]

Webster, John. 2004a. On Evangelical Ecclesiology. Ecclesiology 1: 9-35. [CrossRef]

Webster, John. 2004b. The Goals of Ecumenism. In Paths to Unity: Explorations in Ecumenical Method. Edited by John Cicester. London: Church House Publishing, pp. 1-28.

Webster, John. 2008. Ut Unum Sint: Some Cross-Bench Anglican Reflections. In Ecumenism Today: The Universal Church in the 21st Century. Edited by Francesca Aran Murphy and Christopher Asprey. Aldershot: Ashgate, pp. 29-44.

(C) 2019 by the author. Licensee MDPI, Basel, Switzerland. This article is an open access article distributed under the terms and conditions of the Creative Commons Attribution (CC BY) license (http:/ / creativecommons.org/licenses/by/4.0/). 